\title{
The Challenge of Restoring Debt Sustainability in a Deep Economic Recession: The case of Greece
}

\author{
Platon Monokroussos
}

GreeSE Paper No.87

Hellenic Observatory Papers on Greece and Southeast Europe

OCTOBER 2014 


\section{TABIE OF CONTENTS}

ABSTRACT _ _ iii

1. Introduction __ 1

2. A brief literature review on fiscal multipliers ___ 4

2.1. Determinants of fiscal multipliers ___ 4

2.2. Empirical Studies __ 7

3. Some unpleasant arithmetic of fiscal consolidation ___ 11

3.1 Why fiscal consolidation can lead to an initial rise in the debt ratio__ 11

3.2 Multiplier persistence 13

3.3 Market reaction to fiscal consolidation 15

3.4 Hysteresis _ 17

4. The case of Greece: a simulation exercise ___ 18

5. Concluding remarks __ 27

References _ 30

Appendix 1 - Underlying assumptions___ 32

Appendix 2 - Multiplier persistence __ 33

\section{Acknowledgements}

The author would like to thank an unnamed referee for his valuable comments and suggestions 


\title{
The Challenge of Restoring Debt Sustainability in a Deep Economic Recession: The case of Greece
}

\author{
Platon Monokroussos"
}

\begin{abstract}
The present paper studies the evolution of the Greek public debt ratio under different assumptions regarding the size and the degree of persistence of fiscal multiplies, the implementation profile of the applied fiscal adjustment and the response of financial markets to fiscal consolidation. The main results of our simulation exercise can be summarized as follows: a) taking into account Greece's present debt ratio, a fiscal adjustment can lead to a contemporaneous increase in the ratio if the fiscal multiplier is higher than ca $0.5 ; b)$ despite the unprecedented improvement in the underlying fiscal position since 2010, the concomitant increase in the public debt ratio can be mainly attributed to its high initial level, a very wide initial structural deficit as well as the ensuing economic recession; c) notwithstanding its negative initial effects on domestic economic activity, the enormous fiscal effort undertaken over the last 5 years leaves the country's debt ratio in a more sustainable path relative to a range of alternative scenarios assuming no adjustment or a more gradual implementation profile of fiscal consolidation relative to that implemented thus far.
\end{abstract}

Keywords: Self-defeating consolidations, fiscal multiplier, public debt, Greece, European Commission.

\footnotetext{
\# Deputy General Manager, Chief Market Economist, EFG Eurobank Ergasias S.A. Tel: (+30)210 371 8903, Fax: (+30)210 3337190

e-mail:pmonokrousos@eurobank.gr
} 



\section{The Challenge of Restoring Debt Sustainability in a Deep Economic Recession: The case of Greece}

\section{Introduction}

The large fiscal adjustment undertaken in many advanced economies in recent years has stimulated renewed interest in the effects of fiscal policy on economic activity. To measure these effects, one needs to make an assumption about the size (and the persistence) of fiscal multipliers. ${ }^{1}$ A number of recent empirical studies have demonstrated that fiscal multipliers may be significantly higher in economic downturns than in expansions (see for instance, Auerbach and Gorodnichenko, 2011; Baum and Koester, 2011; Batini et al., 2012; and Blanchard and Leigh, 2013). In a nutshell, while the earlier literature suggests an average first-year (i.e., impact) fiscal multiplier of around 0.6 for advanced economies, there are strong reasons to believe that in the current environment the multiplier may be closer to 1 and, in certain cases, even higher than that. ${ }^{2}$

While a vast volume of theoretical and empirical work exists on the effects of fiscal policy on economic activity (albeit with broadly inconclusive results), the feedback effect from growth to fiscal aggregates, and in particular to government debt, has received less attention. This issue is becoming increasingly important at this juncture as debt reduction has become a key policy target in a number of

\footnotetext{
${ }^{1}$ Fiscal multipliers are defined as the ratio of a change in output to an exogenous change in the fiscal deficit with respect to their baselines.

${ }^{2}$ See e.g. a recent literature review by Mineshima et al. (2013).
} 
advanced economies. In the EU, new provisions in the Stability and Growth Pact require member states with a public debt to GDP ratio higher than $60 \%$ to act to put it on a downward path so as any excess of the ratio over the said threshold decreases by $1 / 20^{\text {th }}$ on a 3 -year rolling basis.

In the case of Greece, an aggressive fiscal consolidation effort has been undertaken since the outbreak of the sovereign debt crisis and the subsequent signing of two consecutive economic stabilization programs. This effort has led to a cumulative adjustment of 19.4ppts of GDP in the cyclically adjusted primary fiscal balance, to a surplus of 5.8\%-of-GDP in 2013, from a deficit of 13.6\%-of-GDP in 2009 (IMF, 2014). Despite this unprecedented improvement (and a number of steps taken in 2012 to restructure privately-held Greek public debt), the country's general government debt ratio has actually increased by $45.3 p p t s$ since 2009 , reaching $175 \%$-of-GDP at the end of 2013 . This development naturally raises the question of whether Greece's fiscal adjustment is actually a "self-defeating" proposition, in the sense that the implementation of aggressive fiscal consolidation in a depressed economy may erode the fiscal balance and worsen debt dynamics on a sustained basis. ${ }^{3}$

The specter of self-defeating consolidations was initially raised in Gros (2011), where a simple framework was utilized to show that austerity could indeed increase the debt ratio in the short-run. However, Gros does not examine the impact of repeated episodes of tightening; neither does he explore the implications of multiplier persistence, two key

\footnotetext{
3 Delong and Summers (2012) argue that under certain conditions even a small amount of "hysteresis" - even a small shadow cast on future potential output by the cyclical downturn - means, by simple arithmetic, that expansionary fiscal policy is likely to be self-financing.
} 
factors that have been subsequently examined in several empirical and are arguably relevant to the Greek case studies (see e.g. European Commission, 2012, and Eyraud and Weber, 2013).

This study presents a simulation exercise for Greece to highlight the effects of the applied fiscal austerity program on the debt ratio and other important fiscal metrics. The paper employs the stock-flow accounting identity, known as intertemporal budget constraint, to study the evolution of the Greek public debt ratio under different assumptions regarding: a) the size and the degree of persistence of fiscal multiplies; b) the size and the implementation profile of the applied fiscal adjustment; and c) the response of financial markets to fiscal consolidation (myopic vs. forward-looking markets).

The main results of our study are as follows: (i) other things being equal, the chances of a "self-defeating" consolidation increase with the initial debt level, the size of the fiscal multiplier and its persistence; (ii) in view of Greece's present elevated debt ratio, a fiscal adjustment can lead to an initial (contemporaneous) rise in the debt ratio if the fiscal multiplier is higher than ca 0.5; (iii) the chance of self-defeating consolidation also increases if financial markets act myopically, by placing a disproportionate weight on the initial rise in the debt ratio following a fiscal policy tightening; (iv) to a large extent, Greece has been sealed from the latter effect, as more than $80 \%$ of its public debt is currently held by the official sector at concessional interest rates that are likely to decrease further following the provision of a new debt relief package by official lenders (expected by to the end of 2014); (v) despite the unprecedented improvement in Greece's underlying fiscal position since 
2010, the concomitant increase in the country's public debt ratio can be mainly attributed to the ratio's elevated initial level, a very wide initial structural deficit as well as the deep economic recession. The aforementioned factors have led to an increase in the debt ratio that is likely to prove temporary; and (vi) notwithstanding its negative initial effects on domestic economic activity, the enormous fiscal effort undertaken in the last 4-5 years leaves the country's debt ratio in a more sustainable path relative to a range of alternative scenarios assuming no adjustment or a more gradual implementation profile of fiscal consolidation.

The rest of the paper is structured as follows. Section 2 provides a brief literature review on fiscal multipliers. Section 3 presents some unpleasant arithmetic of fiscal consolidations. Section 4 presents the main results of our simulation exercise and analyzes their policy implications. Section 5 concludes.

\section{A brief literature review on fiscal multipliers}

\subsection{Determinants of fiscal multipliers}

Prior theoretical and empirical work on the response of main macroeconomic aggregates to exogenous fiscal shocks has shown that the size and, in certain instances, the sign of the fiscal multiplier can be country-, estimation method-, and economic conditions-specific. In general, it appears that quite diverse views continue to exist among professional economists and policy makers as regards the quantitative and qualitative effects of fiscal policy (see e.g. Perotti, 2004). 
From a purely theoretical perspective, neoclassical models would predict that a positive shock to government spending would lead to a crowding out of private consumption, while Keynesian and some neo-Keynesian models would predict the opposite effect. To complicate things further, uncertainty regarding the size (or even the sign) of the fiscal multiplier in developing and emerging markets is even higher, not only because of the scarcity of timely and reliable national and government account statistics, but also because of a long history of fiscal profligacy and sovereign debt crises that have blurred the efficacy of any fiscal expansion.

Based on an extensive literature review on the topic, Spilimbergo et al. (2011) provide some stylized facts on the potential size and determinants of fiscal multipliers. As per the said study, the size of the multiplier is large if: "leakages" are limited i.e., only a small part of the fiscal stimulus is channeled to savings or imports; monetary conditions are accommodative i.e., a fiscal stimulus does not lead to an increase in the interest rate; and the country's fiscal position is sustainable following a fiscal expansion.

Elaborating further on the aforementioned conditions, the authors clarify that leakages are limited if: (i) the propensity to import is relatively small, meaning that large closed economies usually feature larger multipliers than small open economies with no barriers to trade; (ii) the measures mainly target liquidity constrained consumers; that is, an exogenous fiscal shock (e.g. increase in government spending) does not lead to a rise in precautionary savings by consumers in anticipation of higher taxation in the future. That is because liquidity constrained 
households spend a significant portion of the windfall (e.g. wage increase or increased government purchases of goods and services) to increase current spending; (iii) domestic economic conditions are recessionary and the economy is far from its full employment equilibrium; if such conditions prevail, an increase in government spending does not necessarily lead to an increase in interest rates that could, in turn, crowd out private investment; and (iv) the fiscal stimulus has a large spending component, as the initial shock would then have a more immediate impact on aggregate demand, while households may save part of a tax cut. An important point to make here is that the above condition may not apply to a country featuring an unsustainable fiscal position. In that case, an unwarranted fiscal expansion may further exacerbate investor worries about fiscal sustainability, leading to a further increase in sovereign bond yield spreads and domestic interest rates, causing a crowding out of private investment and reducing the multiplier.

Separately, monetary conditions are accommodative if a fiscal shock (e.g. increased discretionary government spending) does not put upward pressure on the nominal interest rate. On the latter point, a number of recent empirical studies have documented that the fiscal multiplier can rise by a factor of 2 or 3 if the nominal interest rate is at (or very close to) the lower nominal bound of zero percent (a situation akin to the Keynesian liquidity trap).

Other factors potentially influencing the size of the fiscal multiplier include the degree of financial market deepening and liberalization as well as the broader macroeconomic conditions in the domestic 
economy. A relatively low degree of financial intermediation usually implies that liquidity-constrained households and businesses cannot easily borrow to intertemporally smooth consumption and investment and thus, a positive fiscal impulse can lead to higher current consumption (and less precautionary saving) than otherwise the case. Furthermore, heightened macroeconomic uncertainty may induce consumers to increase precautionary savings, decrease their marginal propensity to consume and thus, reduce the size of the multiplier (see e.g. Spilimbergo et al., 2011). That is demonstrated by official U.S. data showing that the 2008 tax rebate has been largely saved. At the other end of the spectrum, one could convincingly argue that the crisis may have actually increased the size of the fiscal multiplier, as the ensuing credit crunch has raised the proportion of liquidity-constrained households and, furthermore, monetary authorities in major industrialized countries have reduced their nominal policy rate towards the zero percent bound.

In view of the ambiguous effects of the recent global economic and financial crisis on the size of the fiscal multipliers, Spilimbergo et al. (2011) caution against re-estimating the size of the multiplier in the present trajectory, on the basis that the crisis may have caused structural breaks in relevant date series.

\subsection{Empirical Studies}

Various methodological approaches have been developed to study the effect of fiscal policy changes on economic activity. As of today, the most promising stand of research which aims to isolate the macroeconomic 
effects of purely exogenous fiscal policy impulses rely on the structural vector-autoregression (SVAR) model, initially proposed by Blanchard and Perotti (2002) and extended by Perotti (2004).

A recent literature review by Mineshima et al, (2013), which updates earlier IMF estimates by Spilimbergo and others (2009), finds first-year multipliers of about 0.8 for government spending and about 0.3 for revenue measures. Since about two-thirds of recent fiscal adjustments in advanced economies rely on spending measures, this implies an average overall impact multiplier of ca 0.6.4 Overall, many empirical studies document a positive response of output to an exogenous government spending increase and a negative response of output to an exogenous rise in government revenue (higher taxation), with the former exceeding the latter in absolute terms.

It should be noted here that an important limitation of the methodological approaches highlighted above is that, by construction, they rule-out state-dependent multipliers. Yet, recent empirical work has emphasized that government spending multipliers may be larger in recessions than in expansions. 5 Using an estimation approach similar in many respects to the Smooth Transition Autoregressive (STAR) models developed in Granger and Teravista (1993), Auerbach and Gorodnichenko (2010) estimate spending multipliers that are approximately zero in expansions and as high as 2.0 in recessions. Other

\footnotetext{
${ }^{4}$ However, as noted in the IMF's World Economic Outlook of October 2012 (Box 1.1, page 41), "The main finding, based on data for 28 economies, is that the multipliers used in generating growth forecasts have been systematically too low since the start of the Great Recession, by 0.4 to 1.2 , depending on the forecast source and the specifics of the estimation approach. Informal evidence suggests that the multipliers implicitly used to generate these forecasts are about 0.5 . So, actual multipliers may be higher, in the range of 0.9 to 1.7 ".

${ }^{5}$ For a discussion on these and other related issues see e.g. Auerbach and Gorodnichenko (2010).
} 
recent studies broadly confirm the existence of sizeable cyclical variations of fiscal multipliers. Among others, Bachmann and Sims (2011), report that the spending multiplier is approximately zero in expansions and approximately 3 in recessions. Separately, Shoag (2010) examines state-level variation in government spending and finds that the multiplier is approximately 3.0-3.5 when labor markets have a slack (recession) and approximately 1.5 when there is no slack (expansion). These findings seem to be in agreement with earlier Keynesian arguments in favor of using discretionary fiscal policy in recessionary periods to stimulate aggregate demand. Intuitively, when the economy has a slack, expansionary government spending shocks are less likely to crowd out private consumption or investment.

For Greece, empirical estimation of fiscal multipliers has long been constrained by the lack of available macroeconomic and fiscal data. In a recent paper, Monokroussos and Thomakos (2012) utilize actual (not interpolated) quarterly general government data reported by Eurostat (relevant series dated back to Q1 1999) to estimate the size of fiscal multipliers in expansionary and contractionary output phases. The study employs the classic SVAR approach to estimate output responses to discretionary fiscal shocks. It also presents a variant of the Smooth Transition Vector Autoregression (STVAR) model presented in Auerbach and Gorodnichenko (2011) to investigate the time- and regimedependent properties of Greece's fiscal multiplies. The main results of the study are as follows: (i) SVAR model estimates indicate government spending multipliers that are not far away from these estimated for Greece in a number of earlier empirical studies i.e., multipliers in the vicinity of 0.5 ; (ii) the STVAR model estimates strongly significant 
government spending multipliers that are as high as 1.32 in recessionary phases along with negative (and broadly insignificant) multipliers for periods of economic expansion; and (iii) the latter finding is particularly pronounced for government wage expenditure, where the estimated multiplier is found to be as high as 2.35 (and strongly significant) in recessionary regimes and negative (and largely insignificant) in economic expansions.

In a more recent study, Monokroussos and Thomakos (2013) employ a Multivariate Threshold Autoregressive Model (TVAR) that has a number of unique features that make it particularly suitable for estimating regime-dependent fiscal multipliers for various important government expenditure and revenue categories. Their main results are as follows: (i) the response of real output to discretionary shocks in government current spending on goods and services and/or government tax revenue depends on the regime in which the shock occurs as well as on the size and direction (expansionary vs. contractionary) of the initial shock; (ii) In general, expansionary or contractionary shocks taking place in lower output regimes (economic downturns) appear to have much larger effects on output - both on impact and on a cumulative basis - than shocks of similar sign and size occurring in upper regimes (economic expansions); (iii) in lower regimes in particular, the contractionary effects on output from a negative fiscal shock (spending cut or tax hike) rise with the absolute size of the shock. In the same vein, the expansionary effects on output from a positive fiscal shock (spending hike or tax cut) increase with the absolute size of the shock. Similar effects apply for fiscal shock taking place in an upper output regime, though to a much lesser extent. 


\section{Some unpleasant arithmetic of fiscal consolidation}

\subsection{Why fiscal consolidation can lead to an initial rise in the debt ratio}

In the absence of stock-flow adjustments, the government debt-to-GDP ratio evolves according to the following (approximate) formula ${ }^{6}$ :

$b_{t}=b_{t-1}\left(1+r_{t}-g_{t}\right)-p b a I_{t}$

where $\boldsymbol{t}$ is the time subscript (years); $\boldsymbol{b}_{\boldsymbol{t}}$ is the public debt to GDP ratio in year $t$; $\boldsymbol{p b a l}$ is the primary budget balance to GDP ratio; $\boldsymbol{g}$ represents nominal GDP growth; and $\boldsymbol{r}$ is the average nominal effective interest rate on debt. In our study, the latter variable is proxied by the ratio of total interest expenditure in year $t$ over the public debt stock of year $t-1$.

By definition, the general government balance is the sum of a cyclical component and a structural component:

$b a I_{t}=c a b_{t}+c b_{t}$

where $\boldsymbol{c} \boldsymbol{a} \boldsymbol{b}$ is the cyclically adjusted general government balance and $\boldsymbol{c b}$ is the cyclical component of the balance. The cyclical component varies proportionally to the percentage difference of GDP to the respective

\footnotetext{
${ }^{6}$ The formula is derived from the identity $B_{t}=B_{t-1}\left(1+r_{t-1}\right)-P B a l_{t}$, where $B_{t}$ depicts gross public debt in nominal terms. Dividing both sides of the equation by nominal GDP, $Y_{t}$, we get $\frac{B_{t}}{Y_{t}}=\frac{B_{t-1}}{Y_{t-1}}\left(1+r_{t-1}\right) \frac{F_{t-1}}{Y_{t}}-\frac{P B a l_{t}}{Y_{t}}$. The latter can be rewritten as $b_{t}=\frac{b_{t-1}\left(1+Y_{t-1}\right)}{1+g_{t}}-p b a l_{t}$ and approximating $\frac{\left(1+r_{t-1}\right)}{1+g_{t}}$ with $\left(1+r_{t-1}-g_{t}\right)$ we derive the formula in the text.
} 
baseline, with a coefficient equal to the semi-elasticity of budget balance, $\varepsilon^{7}$

In line with Boussard et al. (2012) and others ${ }^{8}$, the size of the annual structural fiscal effort is represented by the annual change in the cyclically adjusted primary balance. Therefore, a permanent fiscal consolidation (or expansion) in year $t$ constitutes a change in $c a b_{t}$ that remains constant (with respect to the baseline) throughout all years onwards.

The fiscal multiplier, $\boldsymbol{m}_{\boldsymbol{t}}$, of year $t$ is defined as the ratio of nominal GDP over a decrease (increase) in the cyclically adjusted primary balance ${ }^{9}$ :

$m_{t} \equiv \frac{d Y_{t}}{d C A P B_{t}}$

where, $\boldsymbol{d}$ is the first-differencing operator, $\boldsymbol{Y}$ represents GDP in levels and CAPB is the cyclically adjusted primary budget balance in levels.

\footnotetext{
7 The EU fiscal framework uses a standard "two-step methodology", which consists in computing the cyclical component of the budget first and then subtracting it from the actual budget balance. In algebraic terms $c a b_{t}=b a l_{t}-c b_{t}$, where $b a l$ stands for the nominal budget balance to GDP ratio and $c b$ for its cyclical component (European Commission, 2013). The determination of the cyclical component of balances in the EU methodology requires two inputs: i) a measure of the cyclical position of the economy (the output gap, $o g_{t}$ ) and ii) a measure of the link between the economic cycle and the budget (cyclical-adjustment budgetary parameter). The product of the two measures gives the cyclical component of the budget, $c b_{t}=\varepsilon * o g_{t}$, which is then subtracted from the headline budget-to-GDP ratio to obtain the $c a b$.

${ }^{8}$ See e.g. European Commission $(2012,2013)$

${ }^{9}$ As we have noted already, fiscal multiplier is defined as the ratio of a change in output to an exogenous change in the fiscal deficit with respect to their corresponding baselines. In the formula presented in the text we divide by the change in the cyclically adjusted primary balance CAPB in order to disentangle the effects of automatic stabilizers i.e., the feedback effect from the change in output on the fiscal balance. Moreover, we implicitly assume that the change in CAPB is orthogonal to the state of the macroeconomy, an assumption crucial for the identification of exogenous fiscal shocks. Such an assumption is central to the identification approach followed in the standard fiscal SVAR framework introduced by Blanchard and Perotti (2002) and extended by Perotti (2004), albeit at quarterly time frequencies.
} 
From equations (1)-(3) and after some arithmetic manipulations, ${ }^{10}$ it can be shown that a fiscal consolidation in year $t$ leads to a contemporaneous increase in the debt ratio (i.e., $\frac{d\left(b_{t}\right)}{d\left(\operatorname{cabp}_{t}\right)} \geq 0$ ) if the following condition is met:

$$
m_{t} \geq \frac{1}{\left[b_{t-1}\left(1+g_{t}\right)+\varepsilon\right]}
$$

which, for a small $g$ can be approximated by the following formula:

$$
m_{t} \geq \frac{1}{b_{t-1}+\varepsilon}
$$

For the case of Greece, taking as a reference ratio the country's Maastricht debt ratio of 2011 (170.3\% of GDP) and a budgetary semielasticity of 0.43 (see European Commission, 2012), the critical value of the fiscal multiplier that prevents a (contemporaneous) rise in the debt ratio following a fiscal adjustment in year $\mathrm{t}$ is around 0.47 . In other words, a fiscal adjustment undertaken in year $t$ (here, $\mathrm{t}=2011$ ) would lead to an initial rise in the debt ratio if the size of the fiscal multiplier in that year is equal or greater than 0.47 .

\subsection{Multiplier persistence}

As we have explained in the previous section, fiscal consolidations may have negative short-run repercussions not only for economic activity but also for aggregate fiscal metrics, especially in the presence of a high initial debt ratio and fiscal multipliers significantly higher than these documented in early studies. To get a clearer understanding of the effects of fiscal austerity on the debt ratio, let us consider the following

\footnotetext{
${ }^{10}$ See e.g. Boussard et al. (2012).
} 
(approximate) relation, which under certain simplifying assumptions describes the contemporaneous (i.e., first year) change in the debt ratio following a 1 percent of GDP consolidation relative to a given baseline ${ }^{11}$ :

\section{$\Delta($ debt_ratio $) * 100 \approx-1+$ multiplier*debt_ratio + multiplier*revenue_ratio

In equation (5) above, the first term (-1) in the right-hand side represents the (positive) direct effect of fiscal consolidation that improves one-to-one the primary fiscal budget and thus, it has a reducing effect on the debt ratio. However, this positive impact is partially offset (and, in certain instances, more than outweighed) by the effects of declining output on government revenues through the interplay of automatic stabilizers; this (numerator) effect is represented by the last term on the right-hand side of the above equation i.e., multiplier*revenue_ratio. In addition to that, the decline in economic activity following fiscal tightening reduces the denominator of debt-toGDP, exerting an increasing effect on the said ratio; the latter effect is represented by the second term in the right-hand side of equation (5) and it is known as the denominator effect.

For a country featuring a debt ratio of, say, $100 \%$, a revenue ratio of $40 \%$ and a fiscal multiplier of 0.6 , a discretionary fiscal tightening of $1 \mathrm{ppt}$-ofGDP lowers the debt ratio (relative to the no-policy-change baseline) by only $0.16 \%$ of GDP in the first year. That is, assuming all others factors remaining unchanged. In the case of Greece, given the country's current debt ratio (ca. 175\%-of-GDP at the end of 2013) and the present general government revenue ratio (ca. 44\%-of-GDP), a fiscal multiplier of, say, 1

\footnotetext{
${ }^{11}$ See Eyraud and Weber (2013).
} 
means that a fiscal tightening of 1ppt-of-GDP would actually increase the debt ratio by 0.45 ppts-of-GDP (relative to the baseline of no consolidation) in the year that the fiscal consolidation is implemented. In more general terms, the aforementioned analysis suggests that, ceteris paribus, the chances of a self-defeating consolidation increase, with the initial debt level, the size of the multiplier and its persistence.

Note that the analysis above describes the contemporaneous (i.e., same year) dynamics of the debt ratio following a 1ppt of GDP fiscal consolidation, under the assumption of a constant average effective interest rate on the overall debt stock. But, what happens if the effects of fiscal consolidation on output persist beyond the year that fiscal consolidation is implemented? What if one assumes that financial markets react in a certain way to a discretionary fiscal policy change e.g. myopically, by concentrating only on the initial rise in the debt ratio (and thus, demanding a higher risk premium in holding the country's debt) or, alternatively, in a more normal i.e., forward looking manner, by demanding a lower risk premium on sovereign debt and thus, compressing the sovereign bond yield spreads? Finally, what happens in the case of repeated consolidations, a situation more akin to the Greek case, given the huge fiscal consolidation implemented over the last 5 years? In the following sections, we will attempt to shed some light on these and other related issues.

\subsection{Market reaction to fiscal consolidation}

From the intertemporal budget constraint in equation (1) that describes debt dynamics, it is apparent that the debt ratio increases with the 
nominal effective interest rate on debt. Thus, assuming that the initial (year $t-1$ ) debt ratio is $100 \%$ of GDP, the average nominal effective interest rate on debt is $4.50 \%$, nominal GDP growth in year $t$ is $0.0 \%$ and the primary fiscal balance is $0.0 \%$ of GDP, then in the absence of stockflow adjustments, the rise in the debt ratio in year $t$ will be $4.5 p p t s$ of GDP. This simple arithmetic example demonstrates the importance of market reaction to a fiscal consolidation, especially in cases where fiscal adjustment leads to an initial rise in the debt ratio. To address this issue, the recent literature distinguishes between myopic markets and more normal i.e., forward looking markets, depending on the sovereign bond yield sensitivity to the thrust of the fiscal consolidation effort and the subsequent change in the debt ratio.

In order to take account of these influences, Boussard et al. (2012) parameterize the change in the average effective interest rate on debt as follows:

$\frac{d\left(r_{t}\right)}{d\left(\operatorname{capb}_{t}\right)}=\boldsymbol{\mu}+\boldsymbol{\gamma} * \frac{d\left(b_{t+\hbar}\right)}{d\left(\text { capb }_{t}\right)}$

where $d\left(r_{t}\right) / d\left(c a p b_{t}\right)$ depicts the change in the average effective interest rate on debt per one unit change in the cyclically-adjusted primary fiscal balance-to-GDP ratio, $\mu$ is the yield sensitivity to fiscal consolidation and $v$ is the yield sensitivity to the debt ratio in year $t+h$ (for $h \geq 1$ ). Here, parameter $h$, the horizon of financial markets, plays a key role. In particular, $h=1$ and $\gamma>0$ indicate that markets exhibit a high degree of myopia by concentrating on the initial rise in the debt ratio following consolidation and thus demanding a higher risk premium for holding the country's sovereign debt. On the other hand, for cases where $\mu<0, \gamma>0$ 
and $h$ is much higher than 1, markets behave in a more normal (i.e., forward-looking) manner, by concentrating on the longer-term fiscal consolidation impact on the debt ratio and thus demanding a lower risk premium. Overall, the analysis presented above suggests that the chances of self-defeating consolidation increase if financial markets act myopically, by placing a disproportionate weight on the initial rise in the debt ratio following a fiscal policy tightening.

In the case of Greece, it is important to note that, to a large extent, the country has been sealed from the aforementioned effects, as more than $80 \%$ of its public debt is currently held by the official sector at concessional interest rates that are expected to decrease further following a new debt relief package (expected before the end of 2014).

\subsection{Hysteresis}

Delong and Summers (2012) suggest that in a depressed economy even a small amount of "hysteresis" - i.e., a small impact on potential output due to the economic downturn - means, by simple arithmetic, that expansionary fiscal policy is likely to be self-financing. Although the authors clarify that their argument "does not justify unsustainable fiscal policies, nor does it justify delaying the passage of legislation to make unsustainable fiscal policies sustainable" it is clear that the notion of hysteresis takes particular importance for fiscal consolidations undertaken during deep economic downturns, where multipliers are likely to be both high and persistent i.e., their recessionary effects stretch well beyond the year that fiscal adjustment is applied. In the following section we present the results of a simulation exercise for 
Greece, which takes into account the potential effects of some on the aforementioned factors on the evolution of the country's public debt ratio.

\section{The case of Greece: a simulation exercise}

This section presents a simulation exercise, which aims to measure the effects on public debt of the fiscal austerity measures that have been implemented in Greece since 2010; and to evaluate the chances of "selfdefeating" consolidation. The results of the simulation exercise (and a brief description of underling scenarios) are depicted in Figures 1 and 2. Furthermore, Table 1 (Appendix 1) shows the evolution of Greek public debt over the period 2011-2030 under a macroeconomic scenario which broadly evolves in line with the revised troika debt sustainability analysis for Greece12 and also assumes that a new debt relief package (OSI) is provided before the end of 2014. In our exercise, the latter is assumed to incorporate: i) a 20-year extension in the average maturity of EU bilateral loans disbursed to Greece in the context of the 1st adjustment program (GLF); ii) a further reduction of the interest rate charged on these loans (to $0.6 \%$ fixed, from $3 \mathrm{~m}$ euribor $+50 \mathrm{bps}$, currently); and iii) a 10 year deferral of GLF interest payments.13 The reason for incorporating the above relief structure in our analysis is to ensure that the revised official targets for the debt ratio in 2020 and 2022 (around

\footnotetext{
${ }^{12}$ European Commission (April 2014) and IMF (July 2013).

13 A more detailed analysis on this debt relief structure is provided in Greece Macro Monitor, "The economic and market significance of the new 5-year government bond issue- Resumed market access and a new debt relief package will greatly lessen the need for additional official sector financing", Eurobank Global Markets Research, April 15, 2014. http://www.eurobank.gr/Uploads/Reports/GREECE MACRO FOCUS April15 2014 5Y Bond issue.p $\underline{\mathrm{df}}$
} 
$125 \%$ of GDP and $112 \%$ of GDP, respectively) are met, under the assumed baseline macro scenario.

Both Figures 1 and 2 below assume that 2010 is the first year that fiscal consolidation is implemented and thus, all relevant variables take their realized values for the year 2009.14 Specifically, for year t0 $=2009$ it is assumed that the general government primary fiscal deficit equals $10.5 \%$ of GDP; the cyclically adjusted primary fiscal deficit equals $13.6 \%$ of (potential) GDP; the nominal effective interest rate on debt equals 4.5\%; nominal GDP growth equals $-0.9 \%$; and the debt to GDP ratio equals $129.8 \%(b 0=129.8 \%)$.

Our exercise also examines two initial values for the first-year (impact) multiplier; namely -1.5 "high multiplier" and -0.5 "low multiplier", while persistence is incorporated in our simulation framework by assuming that the multiplier follows the convex, autoregressive decaying path analyzed in Appendix 2. In our simulation, "high persistence" corresponds to the following parameter values: $\alpha=0.8 \& \beta=0$; and "low persistence" to the following values: $\alpha=0.5 \& \beta=-0.2$. Finally, the simulation scenarios presented in Figures $1 \& 2$ assume a budgetary semi-elasticity with respect to GDP equal to 0.43 .

In more detail, Figure 1 simulates the path of Greek public debt ratio over the period 2010-2020 assuming that: nominal GDP growth evolves in line with potential GDP growth (realized and projected); the average nominal interest rate on debt is fixed at its 2009 realized value (4.50\%) throughout the entire projection horizon (2010-2020); other debt creating flows (besides the snowball effect and the change in the

\footnotetext{
${ }^{14}$ European Commission (April 2014) and IMF Fiscal Monitor (April 2014).
} 
primary balance) are assumed to be fixed at $0.0 \%$ of GDP from 2010 onwards; and there are varying degrees of fiscal adjustment, identified by the assumed path of the annual change in the cyclically-adjusted primary fiscal balance. These paths are briefly described below (see also Box $A$ beneath Figure 1):

Scenario 0 - "Counterfactual - high-multiplier / high persistence" assumes no fiscal consolidation from 2010 onwards (i.e., annual change in the cyclically-adjusted primary balance $=0.0 \%$ of GDP).

Scenario 1- "Full - frontloaded adjustment - high-multiplier / high persistence" assumes that Greece timely implements the full adjustment (realized and projected) envisaged in its present bailout program (i.e., annual change in the cyclically-adjusted primary balance evolves in line with the program's present baseline scenario).

\section{Scenario 2 - "Partial adjustment - high multiplier / high persistence"} assumes annual changes in the cyclically adjusted primary balance in 2010-2016 that are half the size of these assumed in the baseline (i.e., Scenario 1); from 2017 onwards, respective annual changes are assumed to be equal to these envisaged in Scenario 1.

\section{Scenario 3 - "Gradual adjustment 1 - high multiplier / high persistence"} assumes annual changes in the cyclically adjusted primary balance in 2010-2016 that are equal to the arithmetic average of the cumulative size of fiscal effort assumed in Scenario 1; from 2017 onwards, respective annual changes are assumed to be the same with these envisaged in Scenario 1. 
Scenario 4 - "Gradual adjustment 2 - high multiplier / high persistence" assumes that the cumulative change in the cyclically adjusted primary balance in 2010-2016 that materializes in Scenario 1 is now taking place (equiproportionally) over a longer implementation horizon (i.e., over the period 2010-2023); Note that Scenarios 2 to 4 above can be conceptualized in the a hypothetical environment characterized by e.g. increased social unrest and/or an inability/unwillingness of the domestic political system to implement an aggressive consolidation program so as to swiftly correct sizeable long-standing fiscal imbalances.

Scenario 5 - "Full frontloaded adjustment - high-multiplier / low persistence" is the same as Scenario 1, assuming instead a high impact multiplier value and low persistence.

Scenario 6 - "Full frontloaded adjustment - low multiplier / low persistence" is the same as Scenario 1, assuming instead a low impact multiplier value and low persistence. 
Figure 1. Debt-to-GDP ratio evolution, under different fiscal adjustment scenarios using potential GDP growth as the baseline

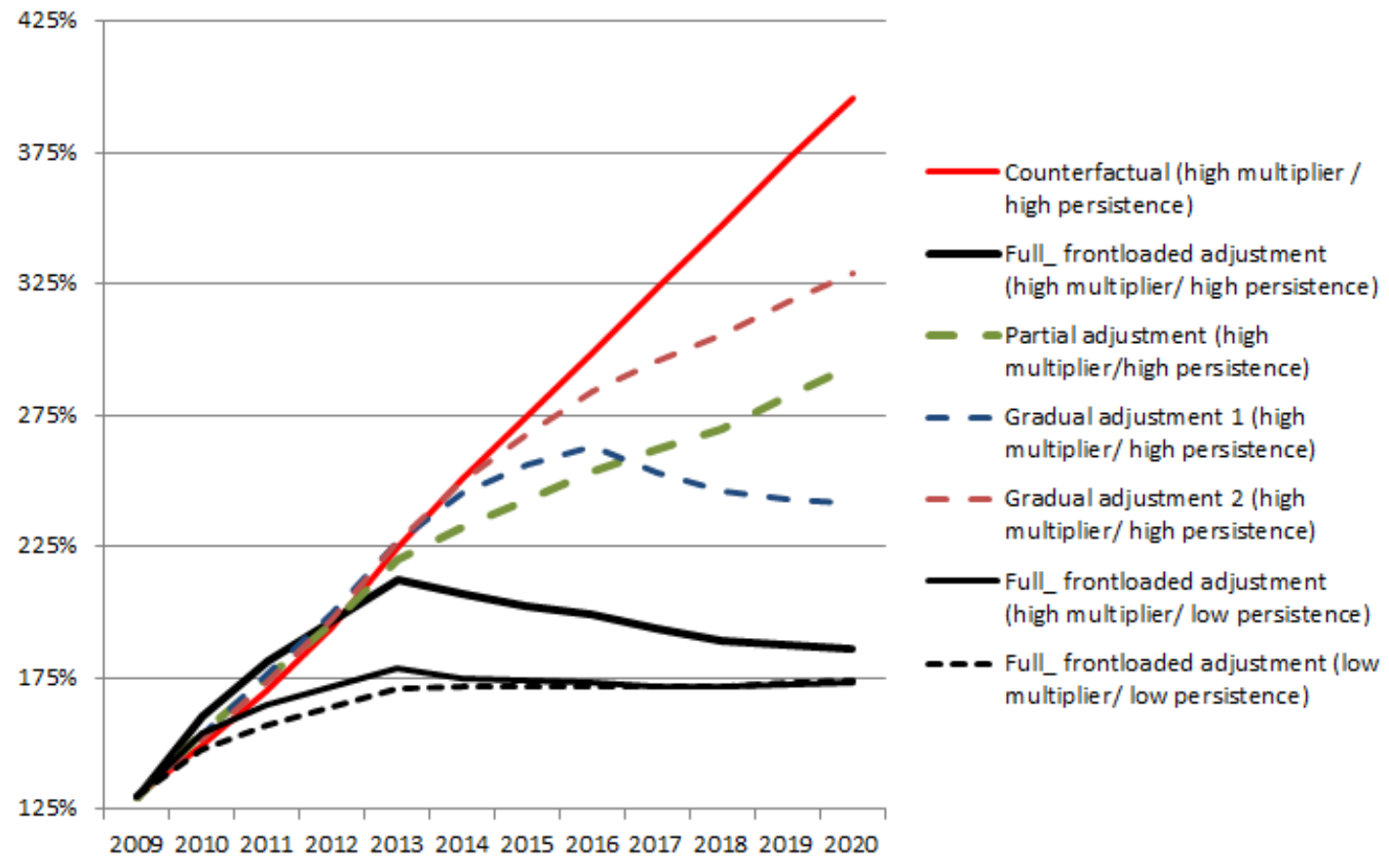

Source: EC (April 2014); IMF (April 2014); Eurobank Global Markets Research. 


\section{Box A - Assumptions and scenarios for the analysis of Figure 1}

Year $\boldsymbol{t}_{0}=\mathbf{2 0 0 9}$ assumptions: General government primary fiscal deficit equals $10.5 \%$ of GDP; Cyclically adjusted primary fiscal deficit equals $13.6 \%$ of (potential) GDP; Nominal effective interest rate on debt equals 4.5\%; Nominal GDP growth equals -0.9\%; Debt ratio equals $129.8 \%\left(b_{0}=129.8 \%\right)$.

Multiplier and automatic stabilizer assumptions: Impact multiplier values: "high" = -1.5; "low" = -0.5; Multiplier persistence parameter values": "high persistence" ( $\alpha=0.8 ; \beta=-0.2)$; "low persistence" $(\alpha=0.5$; $\beta=0)$; Primary balance semi-elasticity with respect to GDP equals 0.43 (see European Commission, 2013).

\section{Scenario 0 - "Counterfactual_high-multiplier/high persistence"}

- Nominal GDP growth = Potential GDP growth (realized \& projected) 2010-2015: in line with IMF WEO (April 2014); FY-2020: in line with IMF's $4^{\text {th }}$ review of Greek program (July 2013); 2015-2020: gradual convergence towards 2020 value;

- Annual change in cyclically adjusted primary balance (i.e., our proxy for the size of fiscal effort) equals $0.0 \%$ from 2010 onwards (no fiscal adjustment scenario);

- Average nominal interest rate on debt fixed at FY-2009 realized value (4.50\%) from 2010 onwards;

- Other debt creating flows (besides the snowball effect and the change in the primary balance) are assumed to be fixed at $0.0 \%$ of GDP from 2010 onwards.

\section{Scenario 1 - "Full_frontloaded adjustment_high-multiplier / high persistence"}

- Nominal GDP growth (before incorporating fiscal multiplier impact) = Potential GDP growth;

- Annual change in cyclically adjusted primary balance (i.e., our proxy for the size of fiscal effort) assumed to evolve in line with IMF's (WEO April 2014) realizations and projections (full fiscal adjustment scenario);

- Average nominal interest rate on debt fixed at FY-2009 realized value (4.50\%);

- $\quad$ Other debt creating flows are assumed to be fixed at $0.0 \%$ of GDP from 2010 onwards.

\section{Scenario 2 - "Partial adjustment_ high multiplier / high persistence"}

- Annual changes in cyclically adjusted primary balance (i.e., our proxy for the size of fiscal effort) in 20102016 are assumed to be half of these assumed in Scenario 1; from 2017 onwards, respective annual changes are assumed to be equal to these envisaged in Scenario 1;

- $\quad$ All other assumptions same as in Scenario 1.

\section{Scenario 3 - "Gradual adjustment 1_ high multiplier / high persistence"}

- Annual change in cyclically adjusted primary balance (i.e., our proxy for the size of fiscal effort) in 20102016 is assumed to be equal to the arithmetic average of the cumulative size of fiscal effort assumed in Scenario 1; from 2017 onwards, respective annual changes are assumed to be the same with these envisaged under Scenario 1;

- $\quad$ All other assumptions same as in Scenario 1.

\section{Scenario 4 - "Gradual adjustment 2_ high multiplier / high persistence"}

- Cumulative change in cyclically adjusted primary balance in 2010-2016 under Scenario 1 is here assumed to take place (equiproportionally) over a longer implementation horizon (i.e., over the period 20102023);

- $\quad$ All other assumptions same as in Scenario 1.

Scenario 5 - "Full_frontloaded adjustment_high-multiplier / low persistence"

- Same as Scenario 1, with "low" multiplier persistence parameter values.

Scenario 6 - "Full_frontloaded adjustment_low multiplier / low persistence"

- Same as Scenario 1, with "low" impact multiplier value and "low" multiplier persistence parameters. 
The graphical depiction of the aforementioned scenarios in Figure 1 suggests that despite an initial (temporary) rise in the debt ratio under full frontloaded adjustment (above the levels envisaged in all other scenarios), the former is clearly superior from a fiscal sustainability perspective, as all other scenarios lead to either explosive debt dynamics or a stabilization of the debt ratio at much higher levels relative to the baseline.

A similar conclusion is drawn from the inspection of Figure 2, with the main difference now being that the latter incorporates different assumptions as regards GDP growth (realized and projected). Specifically, Figure 2 incorporates the same assumptions as Figure 1 as regards: a) the initial values of all relevant variables in year 2009; b) impact multipliers and persistence parameters; and c) fiscal adjustment paths. However, the main difference with the scenarios presented in the previous table is that Figure 2 incorporates the realized GDP values (2010-2013) and the GDP projections envisaged in Greece's present economic adjustment program. This effectively renders our baseline "full adjustment" scenario in Figure 2 tantamount to the present baseline DSA scenario of the Greek adjustment program (European Commission, 2014). Note also that all alternative scenarios (i.e., other than the "full adjustment" baseline) assume similar paths for the nominal effective interest rate and stock-flow adjustments with these envisaged under the baseline. The only exception to this is the "No adjustment nominal IR on debt fixed at 2009 level" scenario, which instead assumes that the average interest rate on debt is fixed at its 2009 value $(4.50 \%)$ throughout the entire projection horizon. 
These assumptions effectively benefit (to a significant degree) all alternative no-full-adjustment scenarios, as they allow them to take advantage of the effects of e.g. the PSI+ and the debt buyback operation conducted in 2012. They also allow them to benefit from the concessional rates on official loans provided to Greece after the country fulfilled major prior actions and milestones in the context of its adjustment programs. Another alternative scenario (not shown in Figure 2) incorporating realized and projected market rates and bond yield spreads, leads to an even steeper explosive path for the debt ratio than these depicted by the no consolidation scenarios in Figure 2 .

Figure 2. Debt-to-GDP ratio evolution, under different fiscal adjustment scenarios using the GDP growth of the revised Greek adjustment program as baseline

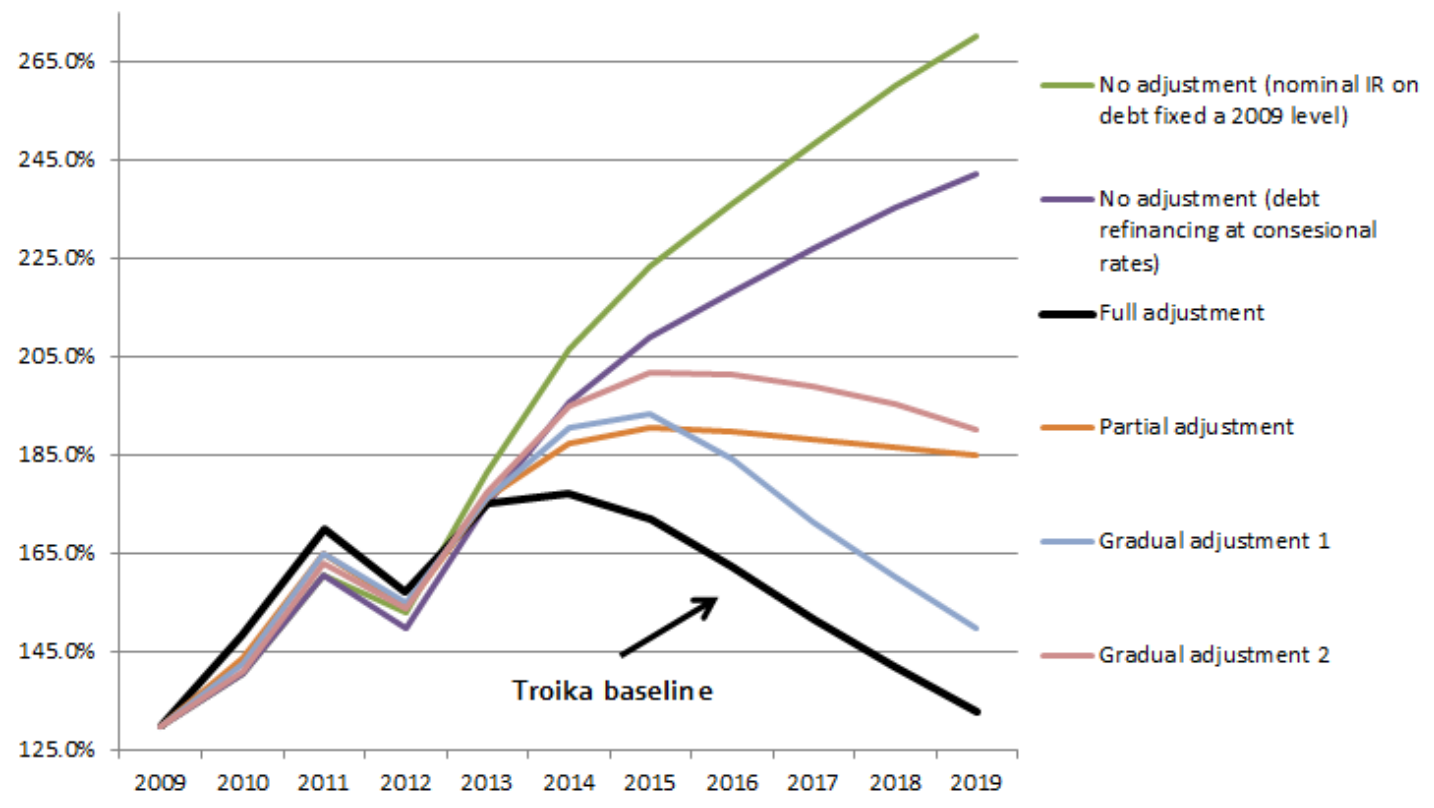

Source: EC (April 2014); IMF (April 2014); Eurobank Global Markets Research 


\section{Box B - Assumptions and scenarios for the analysis of Figure 2}

Year $\boldsymbol{t}_{0}=\mathbf{2 0 0 9}$ assumptions: General government primary fiscal deficit equals $10.5 \%$ of GDP; Cyclically adjusted primary fiscal deficit equals $13.6 \%$ of (potential) GDP;_Nominal effective interest rate on debt equals 4.5\%; Nominal GDP growth equals -0.9\%; Debt ratio equals $129.8 \%\left(b_{0}=129.8 \%\right)$.

Multiplier assumptions: Impact multiplier values: "high" = -1.5 in 2010-2015; "low" = -0.5, from 2016 onwards; Multiplier persistence parameter values": "high persistence" ( $\alpha=0.8 ; \beta=-0.2)$ in 2010-2015; "low persistence" ( $\alpha=0.5 ; \beta=0)$ from 2016 onwards.

Automatic stabilizer assumption: Primary balance semi-elasticity with respect to GDP equals 0.43 (see also European Commission, 2013).

Scenario o - "Full adjustment"

- Underlying assumptions same as in Greece's present economic adjustment program baseline scenario (see also European Commission, 2013).

\section{Scenario 1 - "No adjustment_nominal IR on debt assumed fixed at 2009 level"}

- No fiscal consolidation in 2010-2020 (i.e., annual change in cyclically adjusted primary balance assumed equal to $0.0 \%$;

- Nominal GDP growth in 2010-2020 calculated by extracting from baseline scenario (Scenario 0) the effects of fiscal consolidation assumed in Scenario 0;

- Average nominal interest rate on debt fixed at FY-2009 realized value (4.50\%) from 2010 onwards;

- All other assumptions same as in Scenario 0.

Scenario 2 - "No adjustment_debt refinancing at concessional rates"

- No fiscal consolidation in 2010-2020 (i.e., annual change in cyclically adjusted primary balance assumed equal to $0.0 \%$ );

- Nominal GDP growth in 2010-2020 calculated by extracting from baseline scenario (Scenario 0) the effects of fiscal consolidation assumed in Scenario 0 ;

- Evolution of annual average nominal interest rate on debt assumed equal to that envisaged in Scenario 0 (baseline);

- $\quad$ All other assumptions same as in Scenario 0.

Scenario 3 - "Partial adjustment"

- Annual changes in cyclically adjusted primary balance (i.e., our proxy for the size of fiscal effort) in 20102016 are assumed to be half of these assumed in Scenario 0; from 2017 onwards, respective annual changes are assumed to be equal to these envisaged in Scenario 0;

- Nominal GDP growth in 2010-2020 calculated by extracting from "No adjustment" scenario (Scenario 1) the effects of fiscal consolidation assumed in Scenario 3;

- $\quad$ All other assumptions same as in Scenario 0.

\section{Scenario 4 - "Gradual adjustment 1"}

- Annual change in cyclically adjusted primary balance (i.e., our proxy for the size of fiscal effort) in 20102016 is assumed to be equal to the arithmetic average of the cumulative size of fiscal effort assumed in Scenario 0; from 2017 onwards, respective annual changes are assumed to be the same with these envisaged under Scenario 0;

- Nominal GDP growth in 2010-2020 calculated by extracting from "No adjustment" scenario (Scenario 1) the effects of fiscal consolidation assumed in Scenario 4;

- All other assumptions same as in Scenario o.

Scenario 5 - "Gradual adjustment 2"

- Cumulative change in cyclically adjusted primary balance in 2010-2016 under Scenario 0 is here assumed to take place (equiproportionally) over a longer implementation horizon (i.e., over the period 20102023);

- Nominal GDP growth in 2010-2020 calculated by extracting from "No adjustment" scenario (Scenario 1) the effects of fiscal consolidation assumed in Scenario 5;

- $\quad$ All other assumptions same as in Scenario o. 


\section{Concluding remarks}

This study presents a simulation exercise for Greece to highlight the effects of the applied fiscal austerity program on the debt ratio and other important fiscal metrics. The paper employs the stock-flow accounting identity, known as the intertemporal budget constraint, to study the evolution of the Greek public debt ratio under different assumptions regarding the size and the degree of persistence of fiscal multiplies, the size and the implementation profile of the applied fiscal adjustment as well as the response of financial markets to fiscal consolidation.

The main results of the study are summarized below:

a) in view of Greece's present elevated debt ratio, a fiscal adjustment can lead to an initial (contemporaneous) rise in the debt ratio if the fiscal multiplier is higher than around 0.5;

b) despite the unprecedented improvement in Greece's underlying fiscal position since 2010, the concomitant increase in the country's public debt ratio can be mainly attributed to the ratio's elevated initial level, a very wide initial structural deficit as well as the ensuing economic recession; and

c) notwithstanding its negative initial effects on domestic economic activity, the enormous fiscal effort undertaken in the last 4-5 years leaves the country's debt ratio in a more sustainable path relative to a range of alternative scenarios assuming no adjustment or a more 
gradual implementation profile of fiscal consolidation relative to that implemented thus far.

Although an assessment of the optimal mix of fiscal austerity measures for Greece is beyond the scope of this paper, our analysis suggests that the front-loading nature of the applied adjustment program has been instrumental in stabilizing debt dynamics, especially as the attainment of a primary surplus in the general government accounts in FY- 2013 opens the door for the provision of a new debt relief package by official lenders. As discussed in the paper, the said package is expected to involve further interest rate reductions and loan maturity extensions so as to facilitate fulfilment of the official targets for the public debt to GDP ratio (i.e., ca $124 \%$ in 2020 and $110 \%$ or lower in 2022) and a further reduction of medium-term borrowing needs.

In addition, forward-looking markets have applauded the unprecedented fiscal adjustment Greece has undertaken since the inception of its stabilization program (cumulative improvement in the structural primary balance in excess of 19ppts-of-GDP), compressing the 10-year Greek Government Bond/German Bund yield spread to ca 420bps in mid-June 2014 , from a record of around 3,550bps reached in early 2012. This has allowed the country to re-access financial markets with as many as two sovereign debt issues earlier this year (€3bn of 5-year bonds and €1.5bn of 3-year bonds), as perceived "GREXIT" risks have retreated precipitously since late 2012 .

The sharp compression of sovereign risk premia has also allowed a number of Greek corporations to raise market funding from abroad at a reasonable prices, relaxing the borrowing constraints they have been 
facing in the domestic market and setting the ground for a resumption of domestic investment activity.

True, one can convincingly argue that the implementation of aggressive fiscal austerity has exacerbated the domestic recession (cumulative output losses in excess of $25 \mathrm{ppts}$ over the last six years), not least because recent empirical evidence suggests that fiscal multipliers tend increase in periods of deep economic contractions. However, in the absence of an ambitious (and front-loaded) fiscal adjustment program it would be rather impossible to stabilize investor sentiment towards Greece and correct severe macroeconomic imbalances accumulated in the period leading to the global financial crisis.

Looking ahead, one of the biggest challenges facing the country is to maintain fiscal discipline and complete the program of structural reforms in public administration and the domestic product and services markers agreed with its official lenders, so as to facilitate a return to sustainable and more balanced economic growth. 


\section{References}

Auerbach, Alan J. and Gorodnichenko, Yuriy, 2010, Measuring the output responses to fiscal policy, NBER Working Paper Series, No 16311.

Auerbach, Alan J. and Gorodnichenko, Yuriy, 2011, Fiscal Multipliers in Recession and Expansion, NBER Working Papers, No 17447.

Bachmann, Ruediger and Eric Sims, 2011, Confidence and the Transmission of Government Spending Shocks, NBER Working Papers, No. 17063.

Batini, N. et al., 2012, Successful Austerity in the United States, Europe and Japan, IMF Working Papers, No 12/190.

Baum, Anja and Koester, Gerrit B., 2011, The impact of fiscal policy on economic activity over the business cycle: evidence from a threshold VAR analysis, Discussion paper/Deutsche Bundesbank/Series 1, Economic studies, 03/2011.

Blanchard, Olivier and Leigh, Daniel, 2013, Growth Forecast Errors and Fiscal Multipliers, IMF Working Papers, No. 13/1.

Blanchard, Olivier and Perotti, Roberto, 2002, An Empirical Characterization of the Dynamic Effects of Changes in Government Spending and Taxes on Output, Quarterly Journal of Economics 117(4), p. 1329-1368.

Boussard, Jocelyn et al., 2012, Fiscal Multipliers and Public Debt Dynamics in Consolidations, European Commission Economic Papers, No 406.

Delong, Bradford J. and Summers, Lawrence H., 2012, Fiscal Policy in a Depressed Economy, The Brookings Institution, Brookings Papers on Economic Activity, Spring 2012.

European Commission, March 2012, The Second Economic Adjustment Programme for Greece.

European Commission, September 2013, Effects of fiscal consolidation envisaged in the 2013 Stability and Convergence Programmes on public debt dynamics in EU Member States, European Commission Economic Papers, No 504.

European Commission, April 2014, The Second Economic Adjustment Programme for Greece, Fourth Review.

Eyraud, Luc and Weber, Anke, 2013, The Challenge of Debt Reduction during Fiscal Consolidation, IMF Working Papers, No. 13/67. 
Granger, C. W. and Terasvirta, T., 1993, Modeling Nonlinear Economic Relationships, Oxford Economic Press.

Gros, Daniel, 2011, Can Austerity Be Self-defeating?, VOX, http://www.voxeu.org/article/can-austerity-be-self-defeating.

IMF, March 2009, Global Economic Policies and Prospects, Group of Twenty, Meeting of the Ministers and Central Bank Governors, London, U.K..

IMF, April 2014, Fiscal Monitor.

IMF, April 2014, World Economic Outlook (WEO).

IMF, June 2014, Greece, Country Report No. 14/151.

Mineshima, A. et al., 2013, Fiscal Multipliers, in Post-Crisis Fiscal Policy, C. Cottarelli, P. Gerson, and A. Senhadji (eds.) (forthcoming; Washington, International Monetary Fund).

Monokroussos, Platon and Thomakos, Dimitris, 2012, Fiscal Multipliers in deep economic recessions and the case for a 2-year extension in Greece's austerity programme, Economy \& Markets, Global Markets Research, Eurobank Ergasias S.A.

Monokroussos, Platon and Thomakos, Dimitris, 2013, Greek fiscal multipliers revisited - Government spending cuts vs. tax hikes and the role of public investment expenditure, Economy \& Markets, Global Markets Research, Eurobank Ergasias S.A.

Perotti, R. 2004, Estimating the effects of fiscal policy in OECD countries, Proceedings, Federal Reserve Bank of San Francisco.

Ramey, V.A. and Shapiro, M.D., 1998, Costly Capital Reallocation and the Effects of Government Spending, Carnegie-Rochester Conference Series on Public Policy, No. 48, p. 145-194.

Romer, C. and Romer, D.H., 2010, The Macroeconomic Effects of Tax Changes: Estimates Based on a New Measure of Fiscal Shocks, American Economic Review, No. 100, p. 763-801.

Shoag, Daniel, 2010, The Impact of Government Spending Shocks: Evidence on the Multiplier from State Pension Plan Returns, Harvard University Working paper.

Spilimbergo, A. et al., 2009, Fiscal Multipliers, IMF Staff Position Note, SPN/09/11. 


\section{Appendix 1 - Underlying assumptions}

Table A.1. Evolution of gross public debt ratio \& underlying assumptions

\begin{tabular}{|c|c|c|c|c|c|c|c|c|c|c|}
\hline & 2011 & 2012 & 2013 & 2014 & 2015 & 2016 & 2017 & 2018 & 2019 & 2020 \\
\hline Gross public debt (\% GDP) & 170.2 & 157.2 & 175.0 & 177.1 & 172.1 & 162.2 & 151.7 & 142.1 & 132.7 & $124 \cdot 3$ \\
\hline Nominal public debt (EUR bn) & 354.8 & 303.9 & 318.7 & 322.1 & 323.3 & $319 \cdot 5$ & 313.2 & $307 \cdot 3$ & 300.6 & 293.7 \\
\hline \multicolumn{11}{|l|}{ Memorandoum items } \\
\hline Real GDP Growth & -7.2 & -7.0 & -3.9 & 0.6 & 2.9 & $3 \cdot 7$ & 3.5 & 3.2 & 3.0 & 2.6 \\
\hline GDP deflator inflation & 1.2 & -0.3 & -2.1 & -0.7 & 0.4 & 1.1 & 1.3 & 1.5 & 1.7 & 1.7 \\
\hline Primary fiscal balance (\% GDP) & -2.4 & -1.3 & 0.8 & 1.6 & 3.0 & $4 \cdot 5$ & $4 \cdot 5$ & $4 \cdot 3$ & $4 \cdot 3$ & 4.2 \\
\hline Nominal interest rate on debt (\%) & 4.6 & 2.7 & 2.4 & 2.5 & 3.0 & 3.2 & 3.4 & 3.4 & $3 \cdot 5$ & $3 \cdot 5$ \\
\hline \multirow[t]{2}{*}{ Nominal GDP (EURbn) } & 208.5 & 193.3 & 182.1 & 181.9 & 187.9 & 196.9 & 206.4 & 216.2 & 226.5 & 236.3 \\
\hline & 2021 & 2022 & 2023 & 2024 & 2025 & 2026 & 2027 & 2028 & 2029 & 2030 \\
\hline Gross public debt (\% GDP) & 117.9 & 112.6 & 107.9 & 103.7 & 100.1 & 96.2 & 92.6 & 89.2 & 85.8 & 82.4 \\
\hline Nominal public debt (EUR bn) & $289 \cdot 7$ & 287.6 & 286.3 & 286.1 & 286.8 & 286.6 & 286.8 & 287.0 & 287.2 & 286.7 \\
\hline \multicolumn{11}{|l|}{ Memorandoum items } \\
\hline Real GDP Growth & 2.0 & 1.9 & 1.9 & 1.9 & 1.9 & 1.9 & 1.9 & 1.9 & 1.9 & 1.9 \\
\hline GDP deflator inflation & 1.9 & 2.0 & 2.0 & 2.0 & 2.0 & 2.0 & 2.0 & 2.0 & 2.0 & 2.0 \\
\hline Primary fiscal balance (\% GDP) & 4.0 & 4.0 & 4.0 & 4.0 & 4.0 & 4.0 & 4.0 & 4.0 & 4.0 & 4.0 \\
\hline Nominal interest rate on debt (\%) & 3.6 & 3.6 & 3.6 & 3.8 & 4.0 & 4.1 & $4 \cdot 3$ & 4.6 & 4.7 & 4.7 \\
\hline Nominal GDP (EURbn) & 245.7 & 255.3 & 265.4 & 275.8 & 286.7 & 298.0 & 309.7 & 321.9 & 334.6 & 347.8 \\
\hline
\end{tabular}

Source: EC (April 2014); IMF (June 2014); Eurobank Global Markets Research

Note: Scenario assumes implementation of new debt relief package involving: a) 20-year maturity extension of GLF loans; b) reducing of interest rate on GLF loans from $3 \mathrm{~m}+$ 50 bps currently to $0.6 \%$ fixed; 10 -year grace on GLF interest payments 


\section{Appendix 2 - Multiplier persistence}

In order to incorporate multiplier persistence in our simulation exercise we follow Boussard et al. (2012) and European Commission (2012, 2013) and assume that fiscal multipliers follow the following convex, autoregressive decay path $^{15}$ :

$m_{t, i}=\left(m_{1}-\beta\right) \alpha^{i-t}+\beta$

where, $m_{1}$ is the impact (i.e., first year) multiplier, $m_{t, l}$ is the fiscal multiplier applying in year $i$ following a permanent fiscal shock in year $t$, $0<\alpha<1$; and no assumption made on the sign of 6 i.e., the long-run impulse response of GDP to fiscal consolidation. A negative value of $B$ indicates that "hysteresis" effects are present (see e.g. de Long and Summers, 2012). A positive one represents a situation in which a consolidation today boosts long term growth by e.g. reducing the interest rate and by lessening the crowding out on private investment.

The graph below depicts the decaying path of the fiscal multiplier assumed in the simulation exercise presented in this study. Herein, the initial value of the (impact) multiplier is assumed to take one of the following two values: -1.5 "high multiplier" and -0.5 "low multiplier". Moreover, "high persistence" corresponds to the following parameter values: $\alpha=0.8 \& \beta=-0.2$; and "low persistence" to the following values: $\alpha=0.5 \& \beta=-0$.

\footnotetext{
${ }^{15}$ This decay function reproduces relatively well the shape of the impulse-response function by typical DSGE models for most of the permanents fiscal shocks.
} 
Figure A.1. Response of GDP to one-off cyclical adjustment

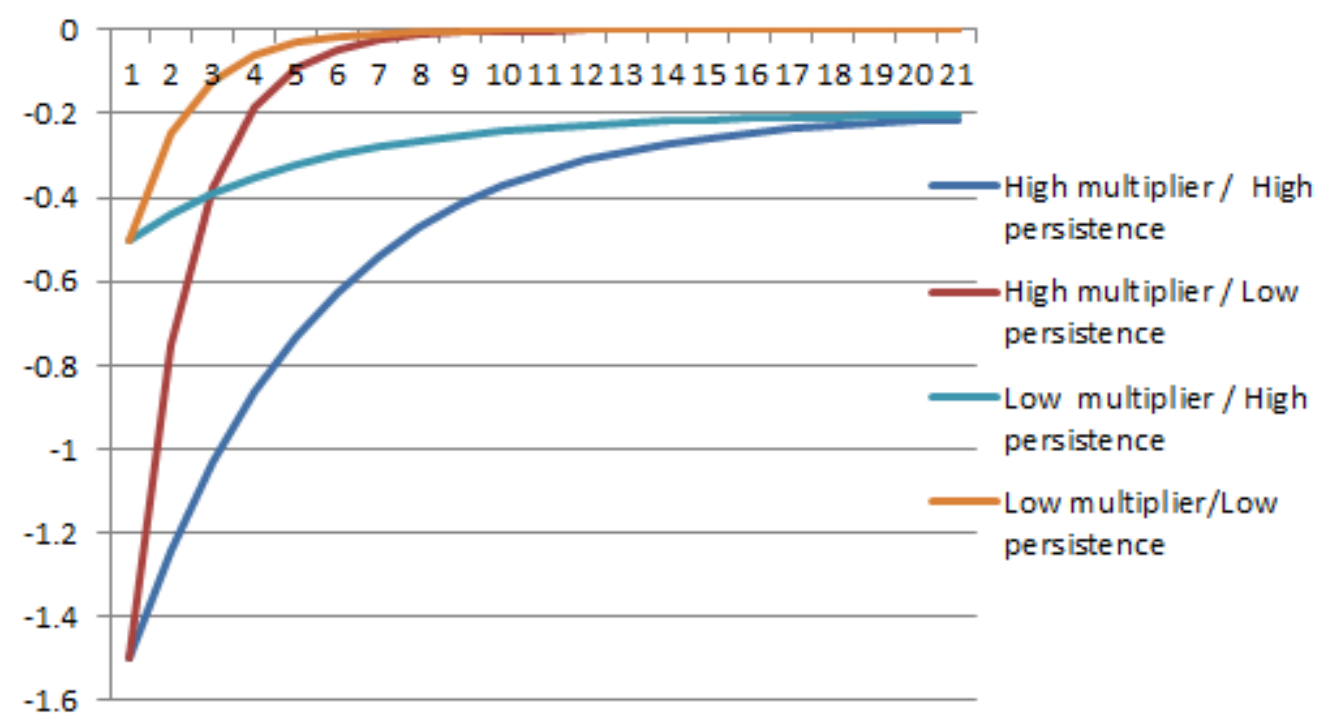

Source: EC (September 2013); Eurobank Global Markets Research

Notes: Response of GDP in years $t=1, \ldots, 21$ per one unit cut in cyclically adjusted primary balance in year $\mathrm{t}=1$. 


\section{Recent Papers in this Series}

86. Thomadakis, Stavros; Gounopoulos, Dimitrios; Nounis, Christos and Riginos, Michalis, Financial Innovation and Growth: Listings and IPOs from 1880 to World War II in the Athens Stock Exchange, September 2014

85. Papandreou, Nick, Life in the First Person and the Art of Political Storytelling: The Rhetoric of Andreas Papandreou, May 2014

84. Kyris, George, Europeanisation and 'Internalised' Conflicts:

The Case of Cyprus, April 2014

83. Christodoulakis, Nicos, The Conflict Trap in the Greek Civil War 19461949: An economic approach, March 2014

82. Simiti, Marilena, Rage and Protest: The case of the Greek Indignant movement,_February 2014

81. Knight, Daniel $\mathbf{M}, \mathbf{A}$ Critical Perspective on Economy, Modernity and Temporality in Contemporary Greece through the Prism of Energy Practice, January 2014

80. Monastiriotis, Vassilis and Martelli, Angelo, Beyond Rising Unemployment: Unemployment Risk Crisis and Regional Adjustments in Greece, December 2013.

79. Apergis, Nicholas and Cooray, Arusha, New Evidence on the Remedies of the Greek Sovereign Debt Problem, November 2013

78. Dergiades, Theologos, Milas, Costas and Panagiotidis, Theodore, Tweets, Google Trends and Sovereign Spreads in the GIIPS,

October 2013

77. Marangudakis, Manussos, Rontos, Kostas and Xenitidou, Maria, State Crisis and Civil Consciousness in Greece, October 2013

76. Vlamis, Prodromos, Greek Fiscal Crisis and Repercussions for the Property Market, September 2013

75. Petralias, Athanassios, Petros, Sotirios and Prodromídis, Pródromos, Greece in Recession: Economic predictions, mispredictions and policy implications, September 2013

74. Katsourides, Yiannos, Political Parties and Trade Unions in Cyprus, September 2013 
73. Ifantis, Kostas, The US and Turkey in the fog of regional uncertainty, August 2013

72. Mamatzakis, Emmanuel, Are there any Animal Spirits behind the Scenes of the Euro-area Sovereign Debt Crisis?, July 2013

71. Etienne, Julien, Controlled negative reciprocity between the state and civil society: the Greek case, June 2013

70. Kosmidis, Spyros, Government Constraints and Economic Voting in Greece, May 2013

69. Venieris, Dimitris, Crisis Social Policy and Social Justice: the case for Greece, April 2013

68. Alogoskoufis, George, Macroeconomics and Politics in the Accumulation of Greece's Debt: An econometric investigation 1974-2009, March 2013

67. Knight, Daniel M., Famine, Suicide and Photovoltaics: Narratives from the Greek crisis, February 2013

66. Chrysoloras, Nikos, Rebuilding Eurozone's Ground Zero - A review of the Greek economic crisis, January 2013

65. Exadaktylos, Theofanis and Zahariadis, Nikolaos, Policy Implementation and Political Trust: Greece in the age of austerity, December 2012

64. Chalari, Athanasia, The Causal Powers of Social Change: the Case of Modern Greek Society, November 2012

63. Valinakis, Yannis, Greece's European Policy Making, October 2012

62. Anagnostopoulos, Achilleas and Siebert, Stanley, The impact of Greek labour market regulation on temporary and family employment Evidence from a new survey, September 2012

\section{Online papers from the Hellenic Observatory}

All GreeSE Papers are freely available for download at http://www.Ise.ac.uk/europeanInstitute/research/hellenicObservatory/pubs/ GreeSE.aspx

Papers from past series published by the Hellenic Observatory are available at http://www.Ise.ac.uk/europeanInstitute/research/hellenicObservatory/pubs/ DP oldseries.aspx 